\title{
Purification of Silicon by the Silicon Fluoride Transport Process A Thermochemical Study
}

Robert A. Rhein

April 15, 1979

Prepared for

U.S. Department of Energy

Through an agreement with

National Aeronautics and Space Administration

by

Jet Propulsion Laboratory

California Institute of Technology

Pasadena, California 


\section{DISCLAIMER}

This report was prepared as an account of work sponsored by an agency of the United States Government. Neither the United States Government nor any agency Thereof, nor any of their employees, makes any warranty, express or implied, or assumes any legal liability or responsibility for the accuracy, completeness, or usefulness of any information, apparatus, product, or process disclosed, or represents that its use would not infringe privately owned rights. Reference herein to any specific commercial product, process, or service by trade name, trademark, manufacturer, or otherwise does not necessarily constitute or imply its endorsement, recommendation, or favoring by the United States Government or any agency thereof. The views and opinions of authors expressed herein do not necessarily state or reflect those of the United States Government or any agency thereof. 


\section{DISCLAIMER}

Portions of this document may be illegible in electronic image products. Images are produced from the best available original document. 


\section{Purification of Silicon by the Silicon Fluoride Transport Process A Thermochemical Study}

Robert A. Rhein

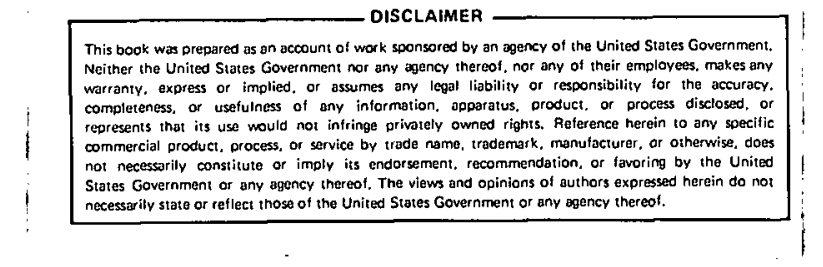

April 15, 1979

Prepared for

U.S. Department of Energy

Through an agreement with

National Aeronautics and Space Administration

by

Jet Propulsion Laboratory

California Institute of Technology

Pasadena, California 
Prepared by the Jet Propulsion Laboratory, California Institute of Technology, for the Department of Energy through an agreement with the National Aeronautics and Space Administration.

The JPL Low-Cost Solar Array Project is sponsored by the Department of Energy (DOE) and forms part of the Solar Photovoltaic Conversion Program to initiate a major effort toward the development of low-cost solar arrays.

This report was prepared as an account of work sponsored by the United States Government. Neither the United States nor the United States Department of Energy, nor any of their employees, nor any of their contractors, subcontractors, or their employees, makes any warranty, express or implied, or assumes any legal liability or responsibility for the accuracy, completeness or usefulness of any information, apparatus, product or process disclosed, or represents that its use wọuld not infringe privately owned rights. 


\section{ABSTRACT}

A computer-assisted thermochemical equilibrium analysis was conducted for the silicon transport reaction:

$$
\mathrm{Si}(\mathrm{s})+\operatorname{SiF}_{4}(\mathrm{~g})=(\text { intermediates })=\operatorname{si}(\mathrm{s})+\operatorname{SiF}_{4}(\mathrm{~g})
$$

The calculations indicated that a substantial transport rate should be possible at temperatures of $1700 \mathrm{~K}$ and one atmosphere pressure.

Computations were made to determine whether the elemental impurities present in metallurgical-grade silicon would transfer in this process. It was concluded that aluminum, chromium, copper, iron, manganese, molybdenum, nickel, vanadium, and zirconium would not transfer, but that boron, magnesium, phosphorus, and titanium would transfer. 
THIS PAGE

\section{WAS INTENTIONALLY \\ LEFT BLANK}


CONTENTS

I. INTRODUCTION -

II. RESULTS AND DISCUSSION - 3

A. COMPUTED SILICON SUBFLUORIDE PRODUCTION

FROM THE REACTION OF Si WITH $\mathrm{SiF}_{4}$

B. COMPUTED DETERMINATION OF IMPURITY TRANSPORT ------- 3

III. CONCLUSIONS --

\section{Figures}

1. The Reaction Between $\mathrm{Si}$ and $\mathrm{SiF}_{4}$ Equilibrium

Composition of Products - 7

2. Computed Reaction Products from the Interaction

of $\mathrm{SiF}_{4}$ and $\mathrm{SiO}_{2}$ at Weight Ratio 1.0

3. Computed Al Reaction Products Resulting from

$1570 \mathrm{ppm} A 1$ in Equimolar $\mathrm{Si}$ and $\mathrm{SiF}_{4}$

4. Computed Al Reaction Products Resulting from

$1570 \mathrm{ppm} \mathrm{Al}$ in Si Reacting with $\mathrm{SiF}_{4}$ in the

Presence of $\mathrm{SiO}_{2}$

5. Computed B Reaction Products Resulting from

$44 \mathrm{ppm} \mathrm{B}$ in $\mathrm{Si}$ with Equimolar $\mathrm{SiF}_{4}$

6. Computed B Reaction Products Resulting from

$44 \mathrm{ppm} \mathrm{B}$ in $\mathrm{Si}$, Reacting with Equimolar $\mathrm{SiF}_{4}$

in the Presence of $\mathrm{SiO}_{2}$

7. Computed Reaction Products from $137 \mathrm{ppm} \mathrm{Cr}$ in Si,

Reacting with Equimolar $\mathrm{SiF}_{4}$

8. Computed Reaction Products from $50 \mathrm{ppm} \mathrm{Mg}$ in $\mathrm{Si}$,

Reacting with Equimolar $\mathrm{SiF}_{4}$

9. Computed Reaction Products from $64.06 \mathrm{ppm} \mathrm{MgF}_{2}$

in $\mathrm{SiF}_{4}$ with $\mathrm{SiO}_{2}$

10. Computed Reaction Products from $70 \mathrm{ppm} \mathrm{Mn}$ in Si, Reacting with Equimolar $\mathrm{SiF}_{4}$

11. Computed Reaction Products from $47 \mathrm{ppm} \mathrm{Ni}$ in $\mathrm{Si}$, Reacting with Equimolar $\mathrm{SiF}_{4}$ 
12. Computed Reaction Products from $28 \mathrm{ppm} \mathrm{P}$ in $\mathrm{Si}$,

Reacting with Equimolar $\mathrm{SiF}_{4}$

13. Computed Reaction Products from $163 \mathrm{ppm} \mathrm{Ti}$ in Si, Reacting with Equimolar $\mathrm{SiF}_{4}$

14. Computed Reaction Products from $100 \mathrm{ppm} \mathrm{Zr}$ in Si, Reacting with Equimolar $\mathrm{SiF}_{4}$ 


\section{SECTION I}

\section{INTRODUCTION}

One of the objectives of the Silicon Material Task of the Low-Cost Solar Array Project (JPL/DOE) is the development of a process for producing $\mathrm{Si}$ at a price of less than $\$ 10 / \mathrm{kg}(1975 \$)$. Included among the various endeavors to accomplish this objective was the purification of commercial metallurgical-grade $\mathrm{Si}$ by the use of a transport process using silicon difluoride as an intermediate compound. A simplified description of the reactions comprising this process (Reference 1) is:

$$
\begin{array}{ll}
\operatorname{Si}(s)+\operatorname{SiF}_{4}(g)=2 \operatorname{SiF}_{2}(g) & (\text { Reaction 1) } \\
\operatorname{xSiF}_{2}(g)=\left(\operatorname{SiF}_{2}\right)_{x}(s) & (\text { Reaction 2) } \\
\frac{2}{x}\left(\operatorname{SiF}_{2}\right)_{x}(s)=\operatorname{Si}(s)+\operatorname{SiF}_{4}(g) & (\text { Reaction 3) }
\end{array}
$$

Reaction 1 has generally been observed at elevated temperatures and reduced pressures: $1623 \mathrm{~K}$ and 0.5 torr (Reference 1); $1473 \mathrm{~K}$ and 0.05 torr (Reference 2); $1423 \mathrm{~K}$ and 0.1-0.2 torr (References 3, 4); $1473 \mathrm{~K}$ and less than $\mathrm{l}$ torr (Reference 5); and $1523 \mathrm{~K}, 0.1-0.2$ torr (Reference 6).

$\mathrm{SiF}_{2}$ is reportedly stable only at low pressures: 5 tor (Reference 2); 0.2 torr (Reference 3); $1-2$ torr (Reference 5); and 0.25 torr (Reference 1 ).

For Reaction 2, the polymerization took place in a cold trap, producing a polymer resembling Teflon, except that the polymer spontaneously ignited in air (Reference 3 ). The cold trap was generally held at the temperature of liquid nitrogen or liquid air; the polymer was observed after the cold trap was warmed to ambient temperature (References 2-6), although infrared spectroscopy studies indicate that polymerization may take place at temperatures as low as $50 \mathrm{~K}$ (Reference 7).

The thermal decomposition of $\left(\mathrm{SiF}_{2}\right)_{x}$ produces polyperfluorosilylene olignmers, including $\mathrm{Si}_{2} \mathrm{~F}_{6}$, that upon heating to above $673 \mathrm{~K}$ further decompose to yield elemental Si (References $1,3-5,8$ ). 
The purpose of this report is to examine the feasibility of this $\mathrm{Si}$ transport process as a means of purification of metallurgicalgrade Si. Two aspects are dealt with here: determination of Si subfluoride yields vs temperature and pressure, and determination of which of the impurity elements present in metallurgical-grade Si might be expected to transfer (as fluorides) in Reaction 1.

The method used here is a computer-assisted thermodynamic. equilibrium analysis of the reaction of $\mathrm{Si}$ with $\mathrm{SiF}_{4}$, assuming the presence of small concentrations of the impurity elements. The computer program is from NASA-Lewis and is described by Gordon and McBride (Reference 9). The following impurity elements, and their concentrations ( $\mathrm{ppm} w \mathrm{t}$ ) in metallurgical-grade $\mathrm{Si}$, are (Reference 10): $\mathrm{Al}, 1570 ; \mathrm{B}, 44 ; \mathrm{Cr}, 137 ; \mathrm{Cu}, 50 ; \mathrm{Fe}, 2070 ; \mathrm{Mg}, 50 ; \mathrm{Mn}, 70 ; \mathrm{Mo}$, $50 ; \mathrm{Ni}, 47 ; \mathrm{P}, 28 ; \mathrm{Ti}, 163 ; \mathrm{V}, 100 ;$ and $\mathrm{Zr}, 100$.

The thermodynamic data for these elements, their fluorides, and, where available, their silicides, were obtained primarily from JANAF tables. Some of the data were obtained courtesy of Dr. Sanford Gordon at NASA-LEWIS and Dr. C. A. Alexander at Battelle Institute, and the remainder were obtained from the collections of Barin and Knacke (References 11, 12) and from a paper by Brewer et al (Reference 13).

The concern with impurities arises from the fact that very small concentrations of impurities (in some cases as low as 1 ppba) can seriously degrade the efficiency of solar cells fabricated from this Si (References 14, 15). 
A. COMPUTED SILICON SUBFLUORIDE PRODUCTION FROM THE REACTION OF Si WITH $\mathrm{SiF}_{4}$.

The computed concentrations of $\mathrm{Si}$ fluorides resulting from the reaction of $\mathrm{Si}$ and $\mathrm{SiF}_{4}$ are shown in Figure 1. I It is seen that there is very little reaction anticipated at temperatures less than $1100 \mathrm{~K}$, but there is substantial reaction at the Si melting point, $1695 \mathrm{~K}$. Likewise, the computed concentrations of Si subfluorides increase with decreasing pressure, as might be expected. However, at one atm pressure, there is still appreciable $\mathrm{Si}$ subfluoride concentration predicted.

There are published accounts of the reaction between $\mathrm{Si}$ and $\mathrm{SiF}_{4}$ at pressures in the order of one atm. Ingle (Reference 16) reported that at $1745 \mathrm{~K}$ and $0.67 \mathrm{~atm} \mathrm{SiF}_{4}$, a weight loss of 7.5 $\mathrm{mg} / \mathrm{min}$ was observed for $\mathrm{Si}$ of surface area $1.3 \mathrm{~cm}^{2}$. Kanaan and Margrave (Reference 17) reacted $\mathrm{Si}$ with $\mathrm{SiF}_{4}$ at one atm, 878-1003 $\mathrm{K}$, measured the $\mathrm{Si}$ weight loss, and concluded that a reaction took place that formed $\mathrm{Si}_{2} \mathrm{~F}_{6}$ and possible higher homologues. Wolf (Reference 18) reported that the reaction between $\mathrm{Si}$ and $\mathrm{SiF}_{4}$ at one atm pressure and $1423 \mathrm{~K}$ produced $\mathrm{Si}_{2} \mathrm{~F}_{6}$ at an efficiency of approximately $7 \%$ and that the $\mathrm{SiF}_{2}$ production rate should increase with the square root of the $\mathrm{SiF}_{4}$ pressure (production rate is the product of concentration and total pressure).

It is conceivable that the step involving $\left(\mathrm{SiF}_{2}\right)_{\mathrm{x}}$ polymer formation and decomposition may not be necessary for $\mathrm{Si}$ transport. Wolf (Reference 18 ) reported $\mathrm{Si}_{2} \mathrm{~F}_{6}$ decomposed to $\mathrm{Si}$ at $823 \mathrm{~K}$. $\mathrm{Si}_{2} \mathrm{~F}_{6}$ and the higher homologues are stable below $673 \mathrm{~K}$, but disproportionate to $\mathrm{Si}_{\text {and }} \mathrm{SiF}_{4}$ upon passage through a tube heated to $1123 \mathrm{~K}$ (Reference 8 ).

\section{B. COMPUTED DETERMTNATION OF IMPURITY TRANSPORT}

Figure 2 shows that for temperatures to $1700 \mathrm{~K}$ and pressures $0.001-1.0 \mathrm{~atm}$, there is very little interaction between $\mathrm{SiO}_{2}$ and $\mathrm{SiF}_{4}$; hence $\mathrm{SiO}_{2}$ can be used as a material of construction up to its softening point, $1773 \mathrm{~K}$ (Reference 19). Figure 3 shows that aluminum would be expected to transfer as the fluoride; however, in the presence of $\mathrm{Sin}_{2}$, Figure 4, Al would not transfer but instead would form the silicate. Ingle (Reference 1) was unable to record the mass spectrum of $\mathrm{AlF}_{3}$ in a heated quart. tube, presumably also because of aluminum silicate formation.

Figures 5 and 6 show that boron is expected to transfer primarily as $\mathrm{BF}_{3}$ in the absence or presence of $\mathrm{SiO}_{2} . \mathrm{BF}_{3}$ reacts with $\mathrm{SiF}_{2}$ at low temperatures (Reference 5) forming $\mathrm{Si}_{2} \mathrm{BF}_{7}$ and possible other Si-B-F compounds. Such compounds may well incorporate into the $\left(\mathrm{SiF}_{2}\right)_{\mathrm{x}}$ polymer. 
Figure 7 shows that the chromium impurity reacts to form the silicide and is not expected to transfer.

Copper was found to be unchanged in the $\mathrm{Si}_{/} \mathrm{SiF}_{4}$ reaction, and is not expected to transfer.

Iron forms the silicide during the reaction, and is not expected to transfer. Figures 8 and 9 show that magnesium is expected. to transfer as the fluoride above $1300 \mathrm{~K}$ in the absence or presence of $\mathrm{SiO}_{2}$.

Molybdenum forms the silicide and is not expected to transfer. Manganese remains as either the element or silicide, Figure 10, and is not expected to transfer. Figure 11 shows that nickel reacts to form the silicide, and is not expected to transfer.

Figure 12 shows that at temperatures above $1100 \mathrm{~K}$, phosphorus (boiling point $704 \mathrm{~K}$, Reference 20) is expected to transfer as the element. Figure 13 shows that for temperatures above $1100 \mathrm{~K}$, titanium is expected to transfer as the fluoride.

Vanadium forms the silicide, and is not expected to transfer. Zirconium is expected to transfer, Figure 14, at temperatures above $1200-1300 \mathrm{~K}$; however, in the presence of $\mathrm{SiO}_{2}, \mathrm{Zr}$ forms the silicate, and would not transfer. 


\section{SECTION III}

\section{CONCLUS IONS}

Thermochemical computations indicate that a substantial transport rate of $\mathrm{Si}$ should be feasible at pressures in the order of one atm. This process should be capable of removing the following impurities from metallurgical-grade $\mathrm{Si}$ in the presence of $\mathrm{SiO}_{2}$ : $\mathrm{Al}$, $\mathrm{Cr}, \mathrm{Cu}, \mathrm{Fe}, \mathrm{Mn}, \mathrm{Mo}, \mathrm{Ni}, \mathrm{V}$, and $\mathrm{Zr}$. However, the following impurities may transfer: $\mathrm{B}, \mathrm{Mg}, \mathrm{P}$, and $\mathrm{Ti}$.

For this $\mathrm{Si}$ transport process to be effective in converting metallurgical-grade $\mathrm{Si}$ to solar-cell-grade $\mathrm{Si}$, other means must be devised to eliminate the $\mathrm{B}, \mathrm{Mg}, \mathrm{P}$, and $\mathrm{Ti}$ impurities. One possibility is the use of $\mathrm{Si}_{2} \mathrm{~F}_{6}$ as the intermediate transport species, along with distillation to remote elemental $P$ and the transported fluorides of $\mathrm{B}, \mathrm{Mg}$, and $\mathrm{Ti}$. 


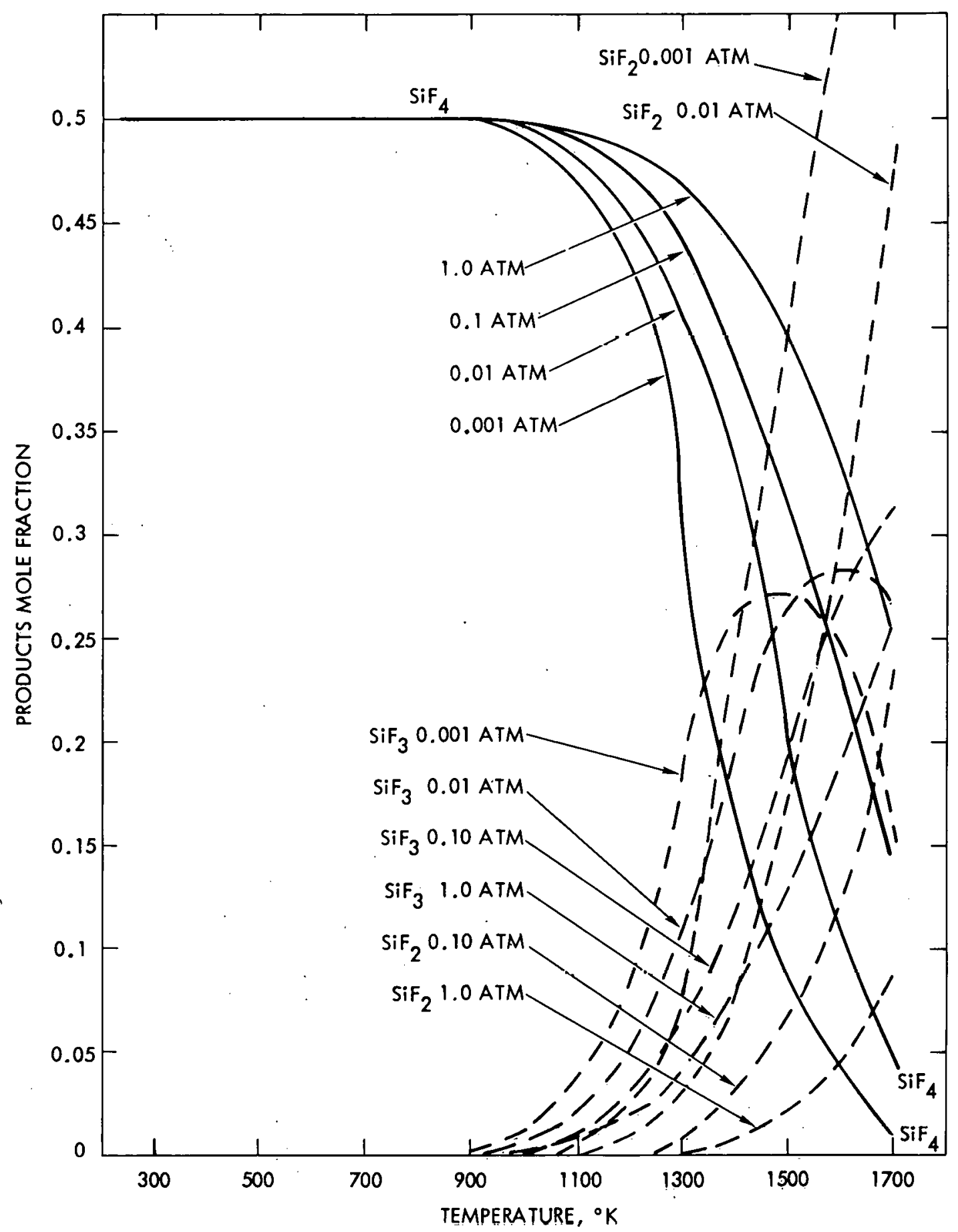

Figure 1. The Reaction Between $\mathrm{Si}$ and $\mathrm{SiF}_{4}$ Equilibrium Composition of Products. Initial Mole fraction of Reactants: SiF4, $0.5 ; \mathrm{Si}, 0.5$ 


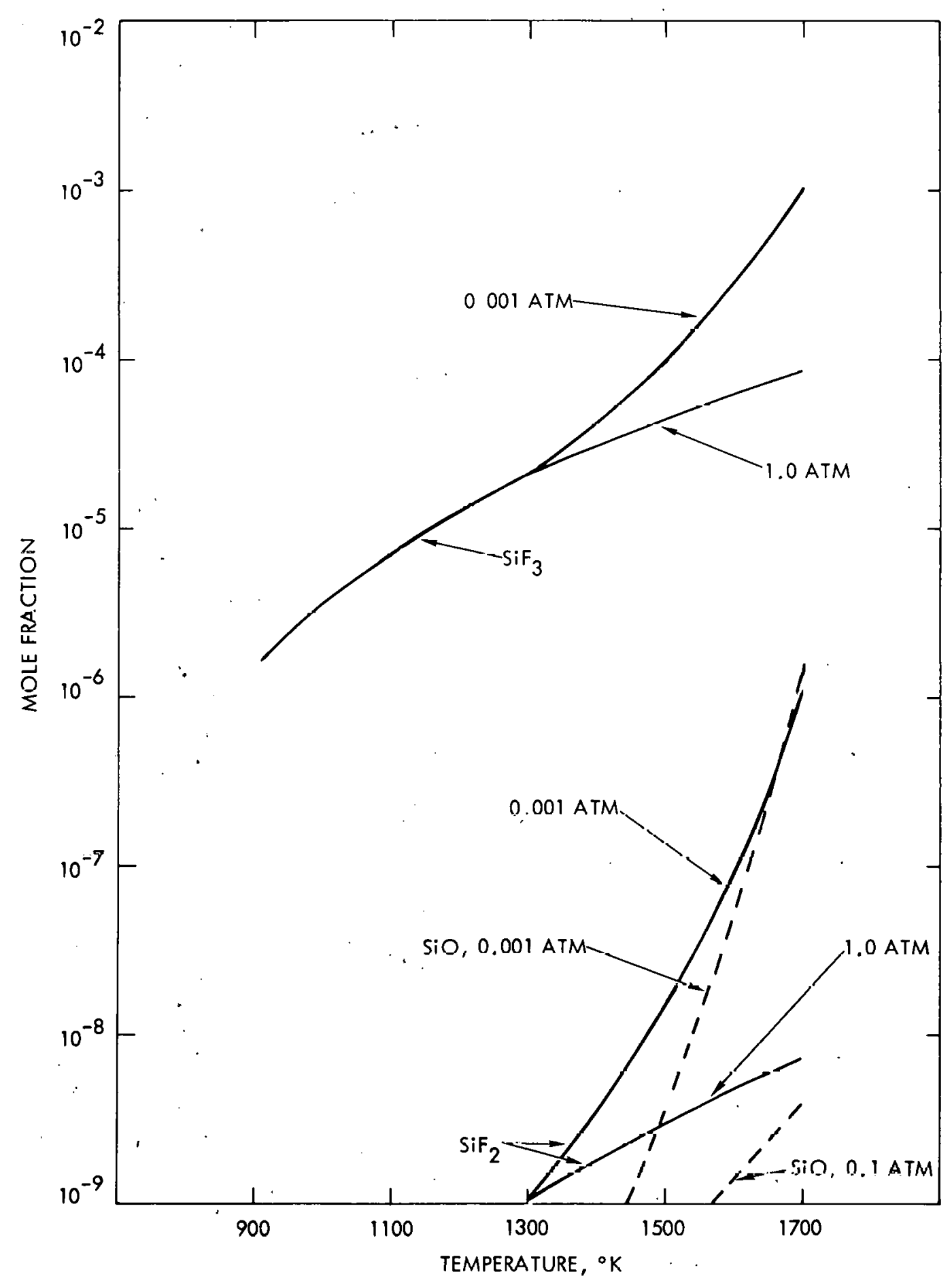

Figure 2. Computed Reaction Products from the Interaction of $\mathrm{SiF}_{4}$. and $\mathrm{SiO}_{2}$ at Weight Ratio 1.0. $\mathrm{SiF}_{4}, \mathrm{SiO}_{2}$ Not Shown, as Mole Fractions Essentially Unaffected 


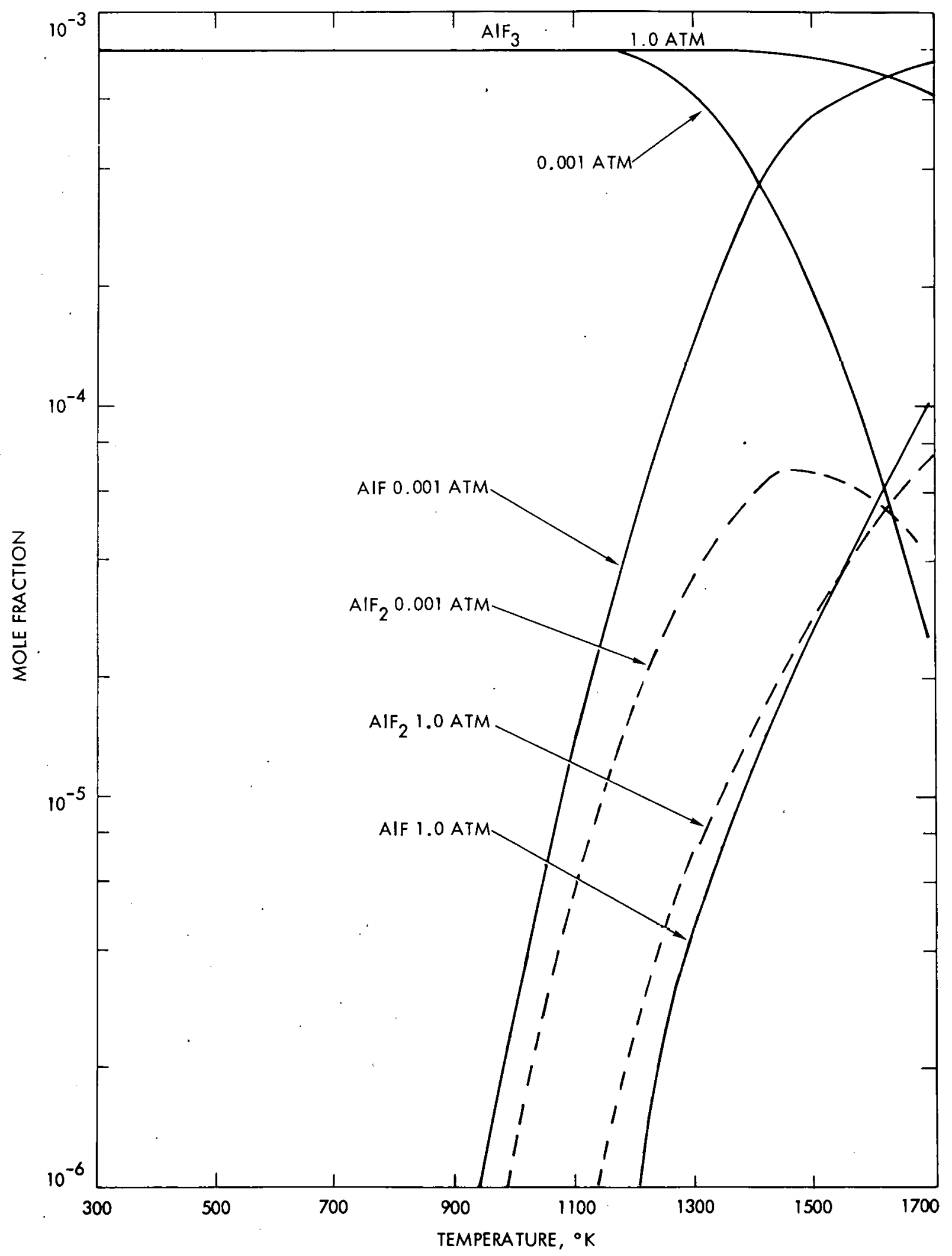

Figure 3. Computed Al Reaction Products Resulting from $1570 \mathrm{ppm} \mathrm{Al}$ in Equimolar'Si and $\mathrm{SiF}_{4}$ 


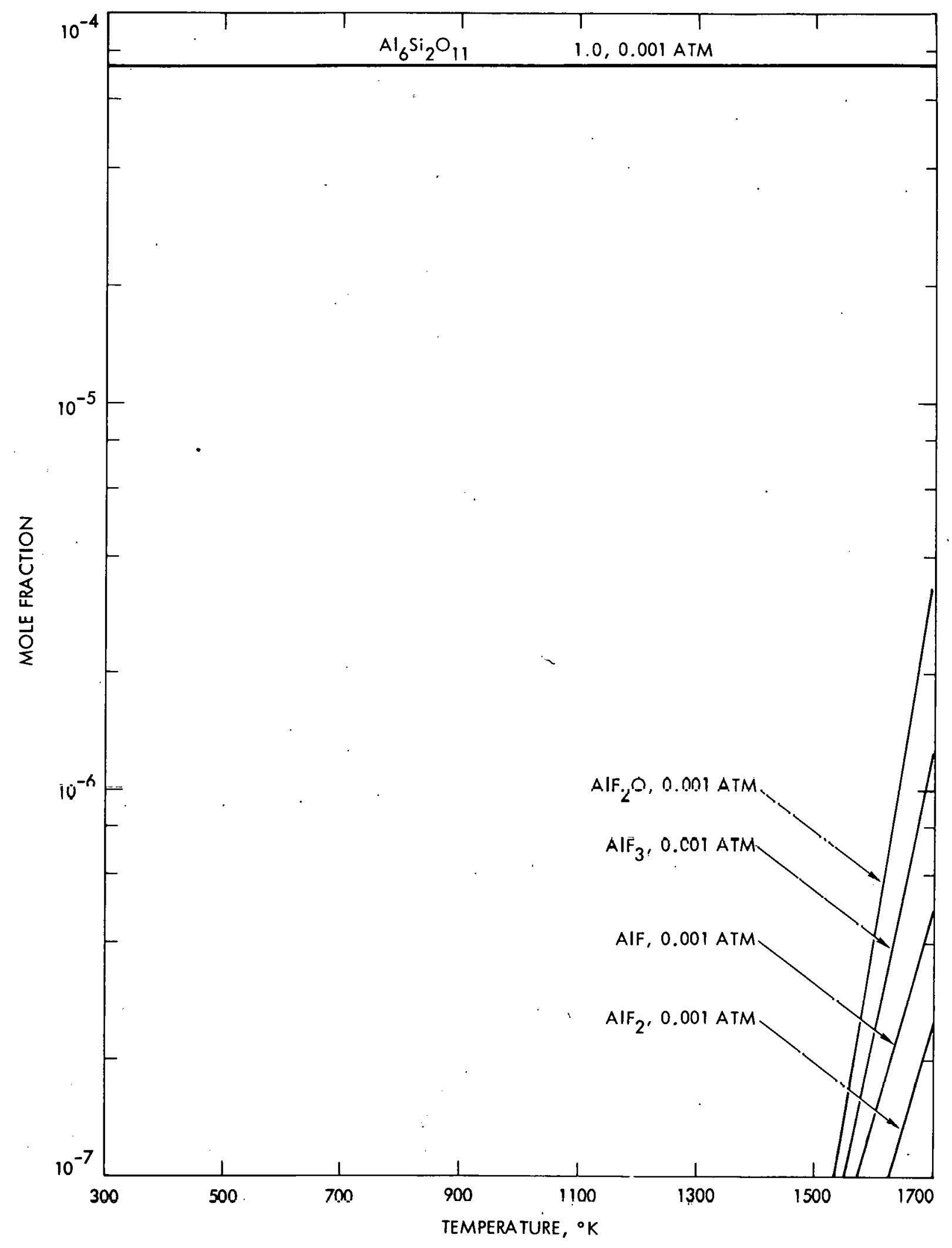

Figure 4. Computed Al Reaction Products Resulting from $1570 \mathrm{ppm} \mathrm{AL}$ in Si keacting with $\mathrm{SiF}_{4}$ in the Presence of $\mathrm{SiO}_{2}$ 


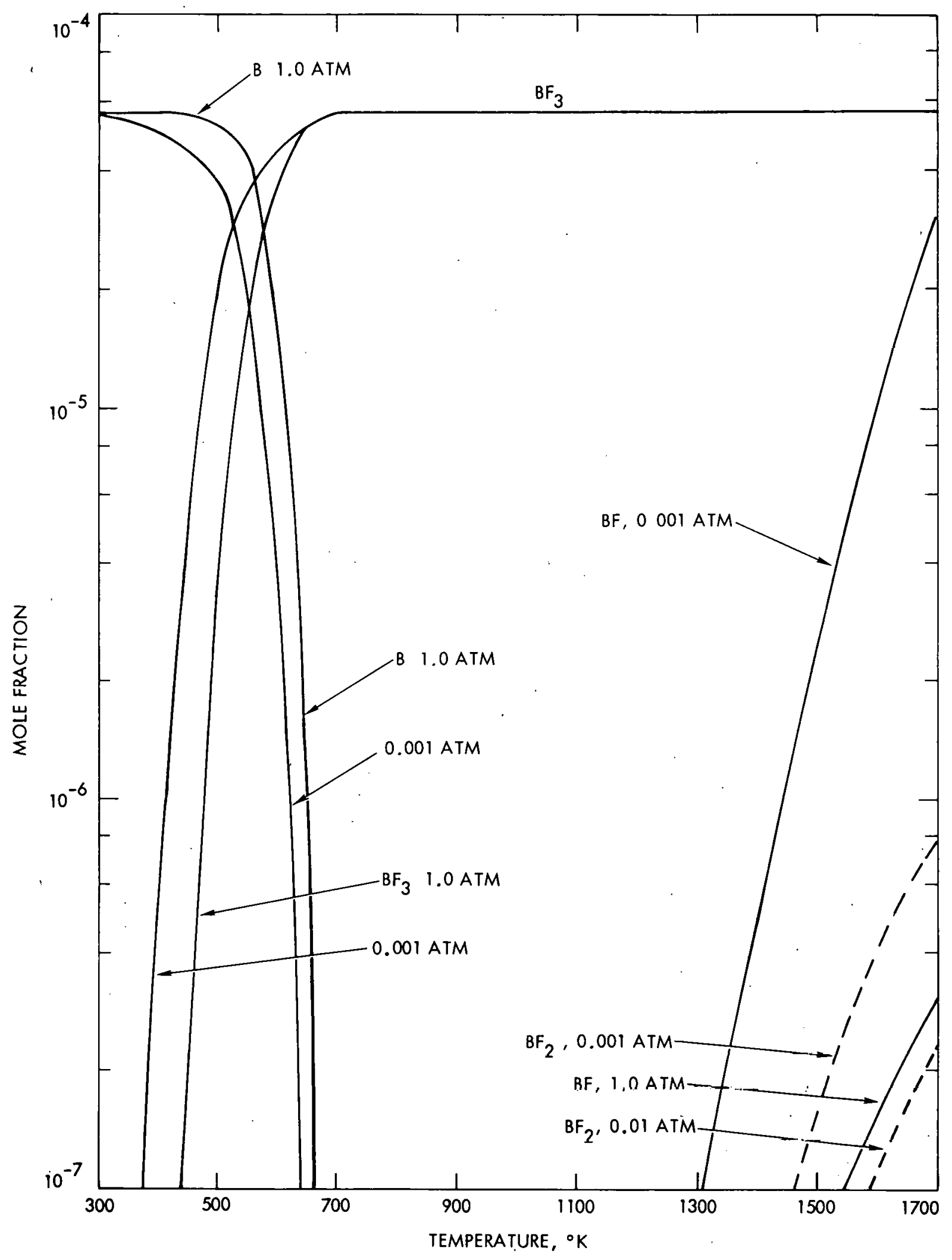

Figure 5. Computed B Reaction Products Resulting from 44 ppm B in $\mathrm{Si}$ with Equimolar $\mathrm{SiF}_{4}$ 


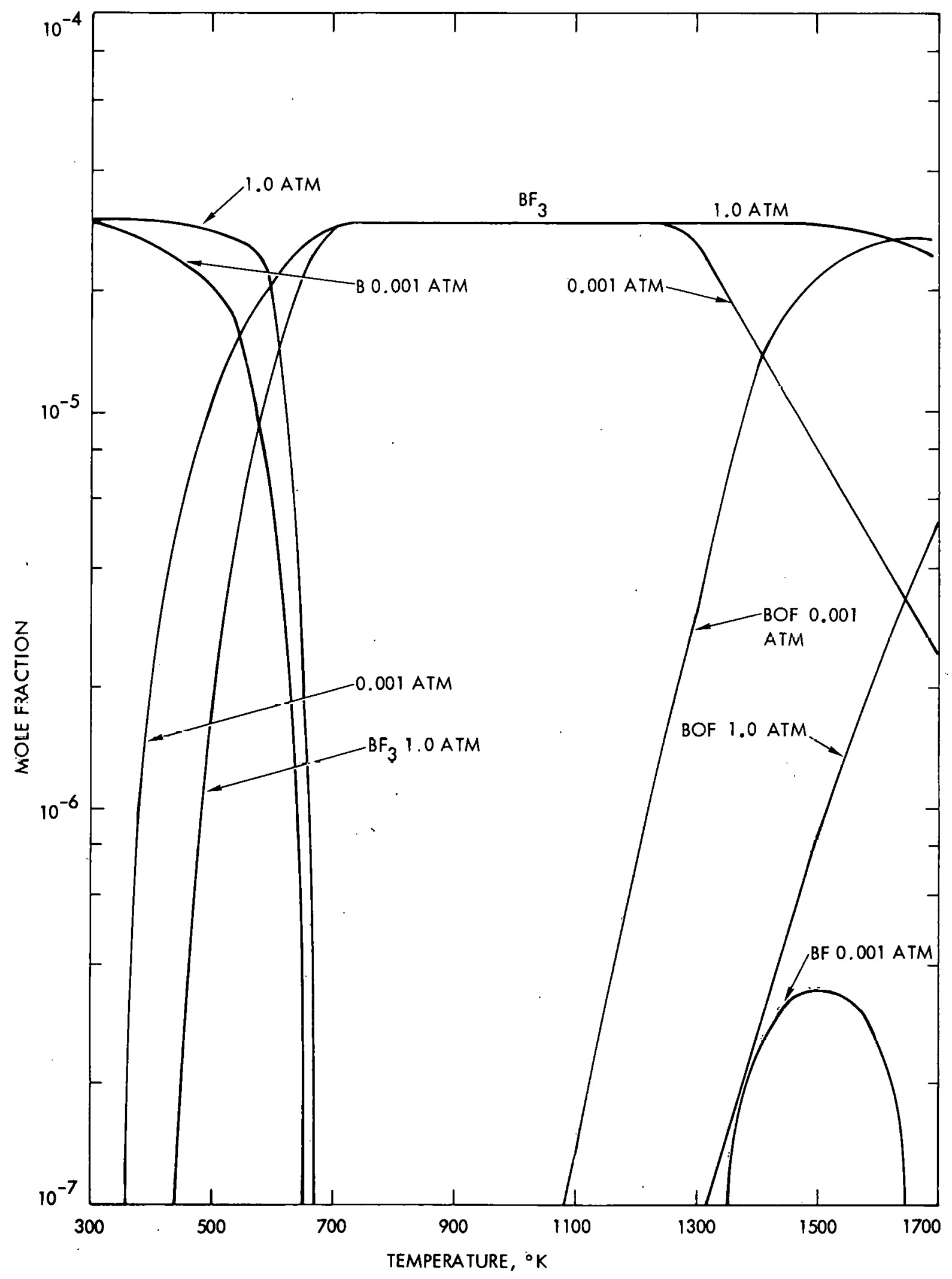

Figure 6. Computed B Reaction Products Resulting from 44 ppm B in Si, Reacting with Equimolar $\mathrm{SiF}_{4}$ in the Presence of $\mathrm{SiO}_{2}$ 


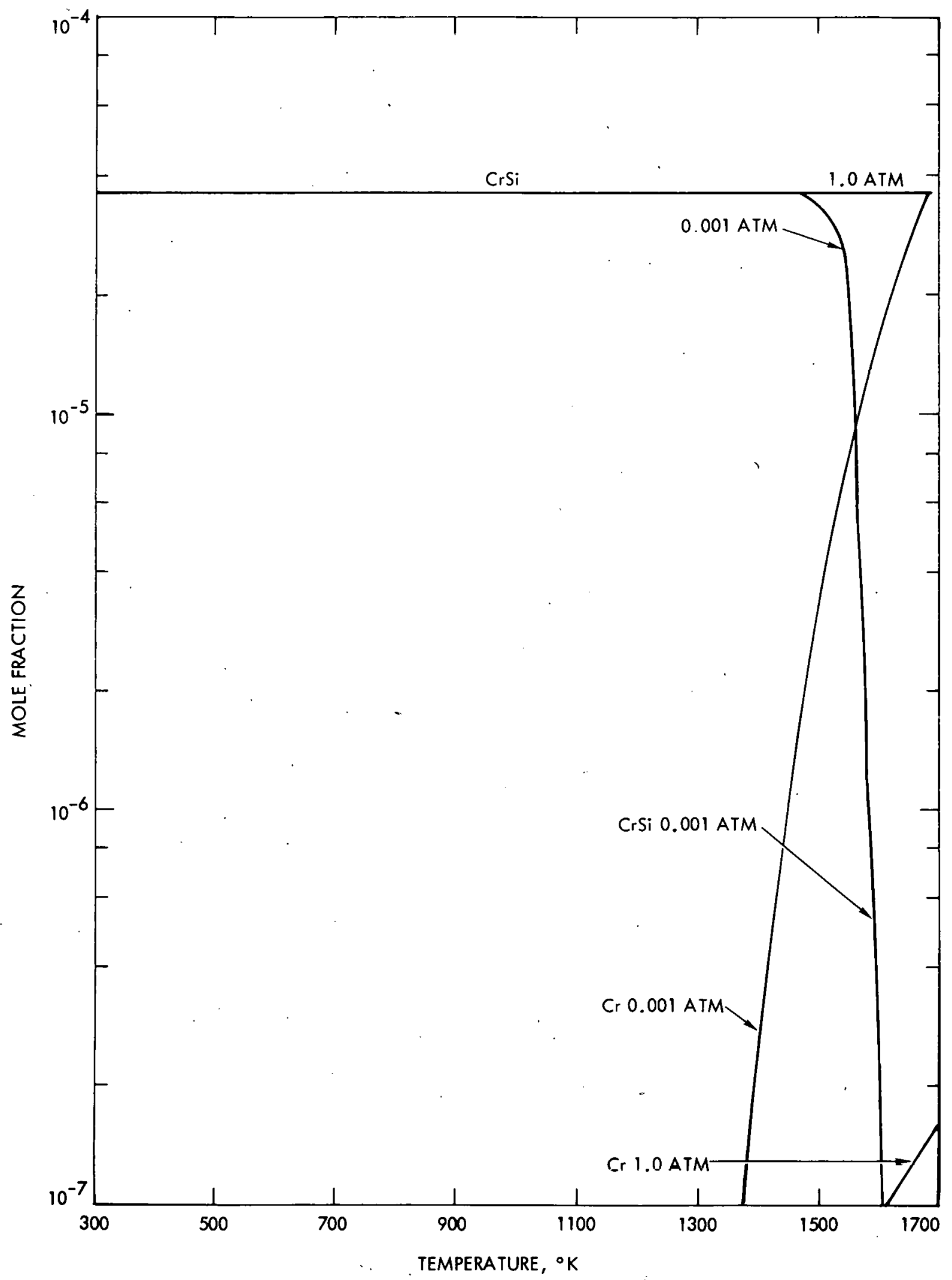

Figure 7. Computed Reaction Products from $137 \mathrm{ppm} \mathrm{Cr}$ in Si, Reacting with Equimolar $\mathrm{SiF}_{4}$ 


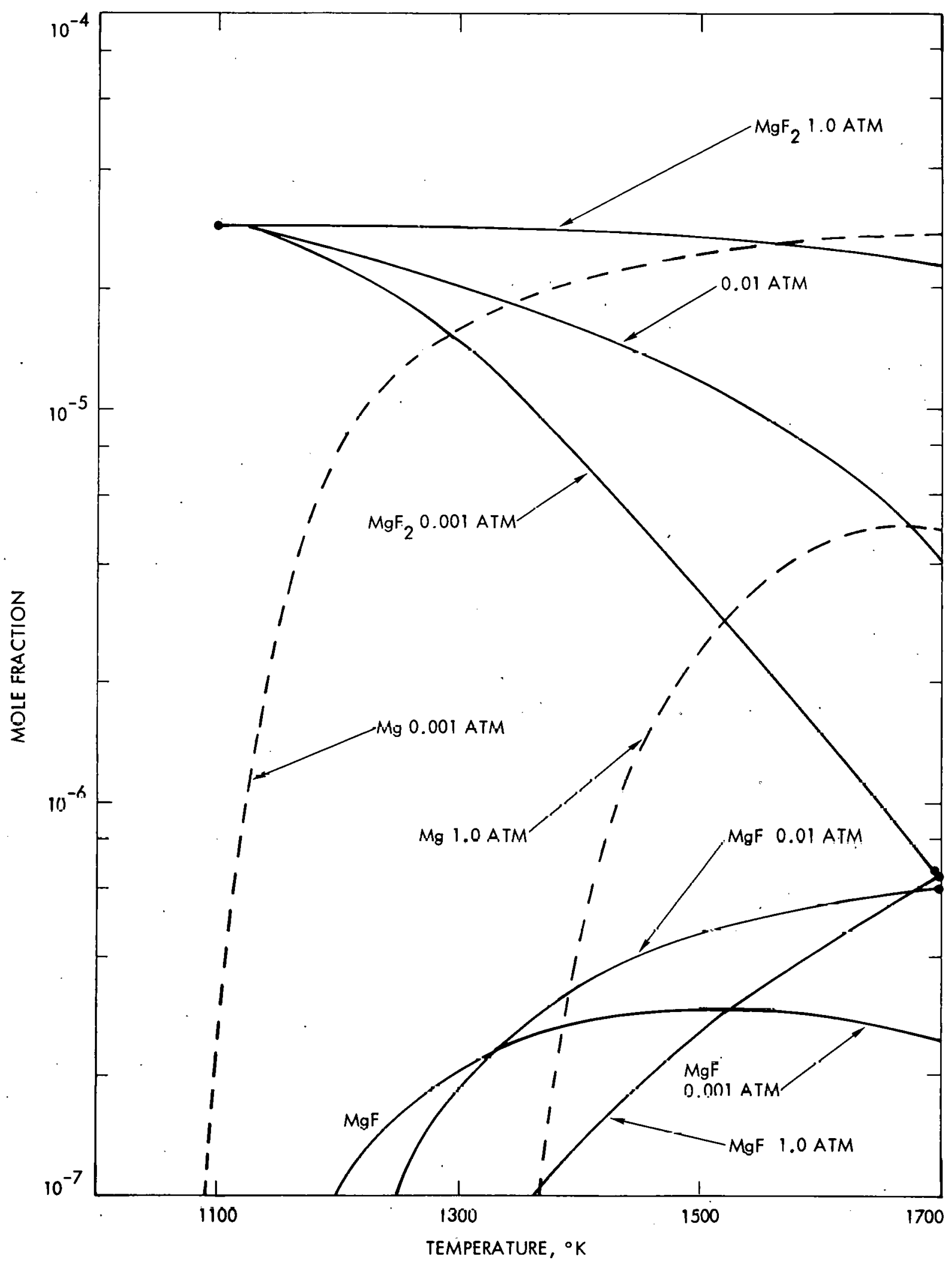

Figure 8. Computed Reaction Producls from $50 \mathrm{ppm} \mathrm{Mg}$ in $\mathrm{Si}$, Reacting with Equimolar $\mathrm{SiF}_{4}$ 


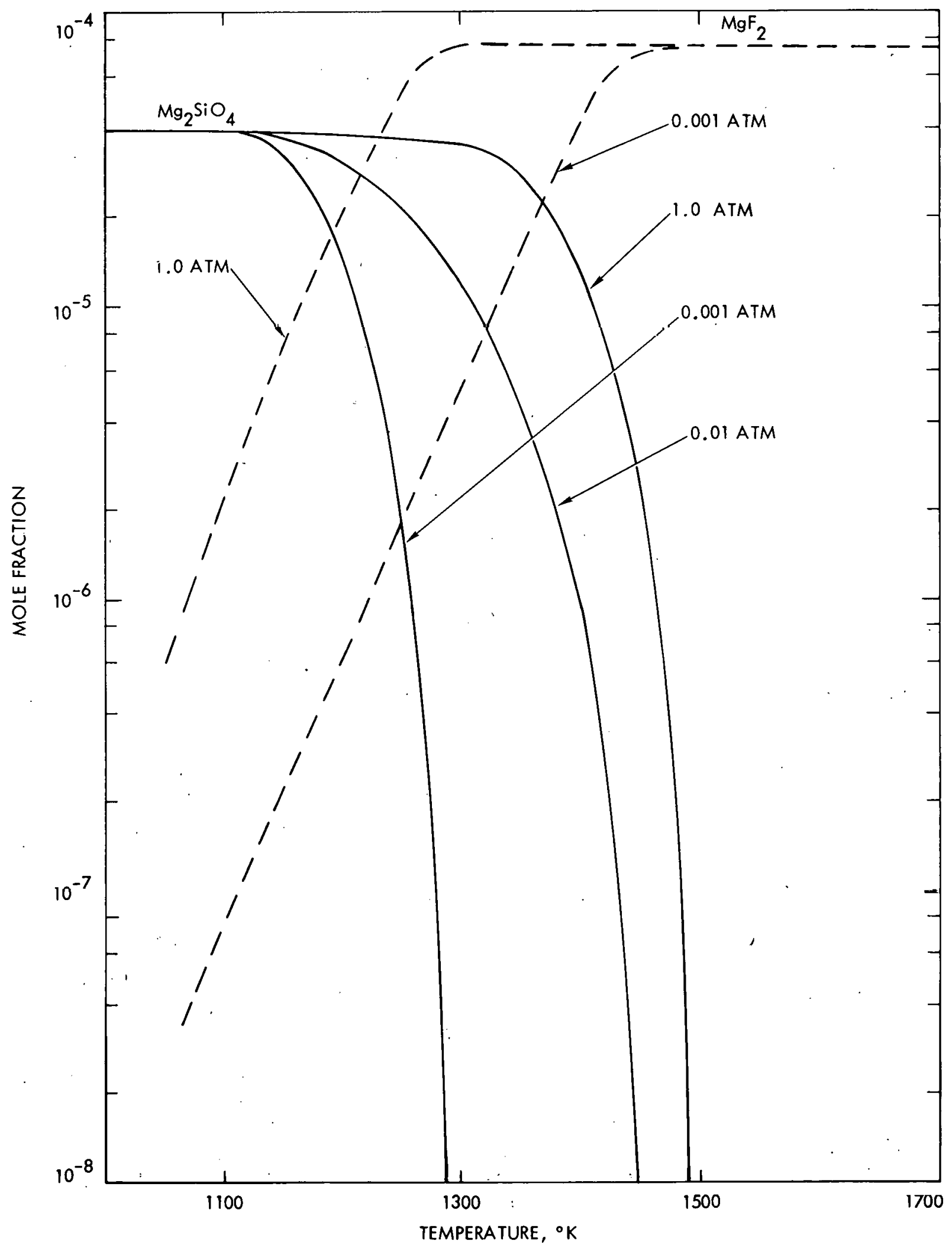

Figure 9. Computed Reaction Products from $64.06 \mathrm{ppm} \mathrm{MgF} 2$ in $\mathrm{SiF}_{4}$ with $\mathrm{SiO}_{2}$ 


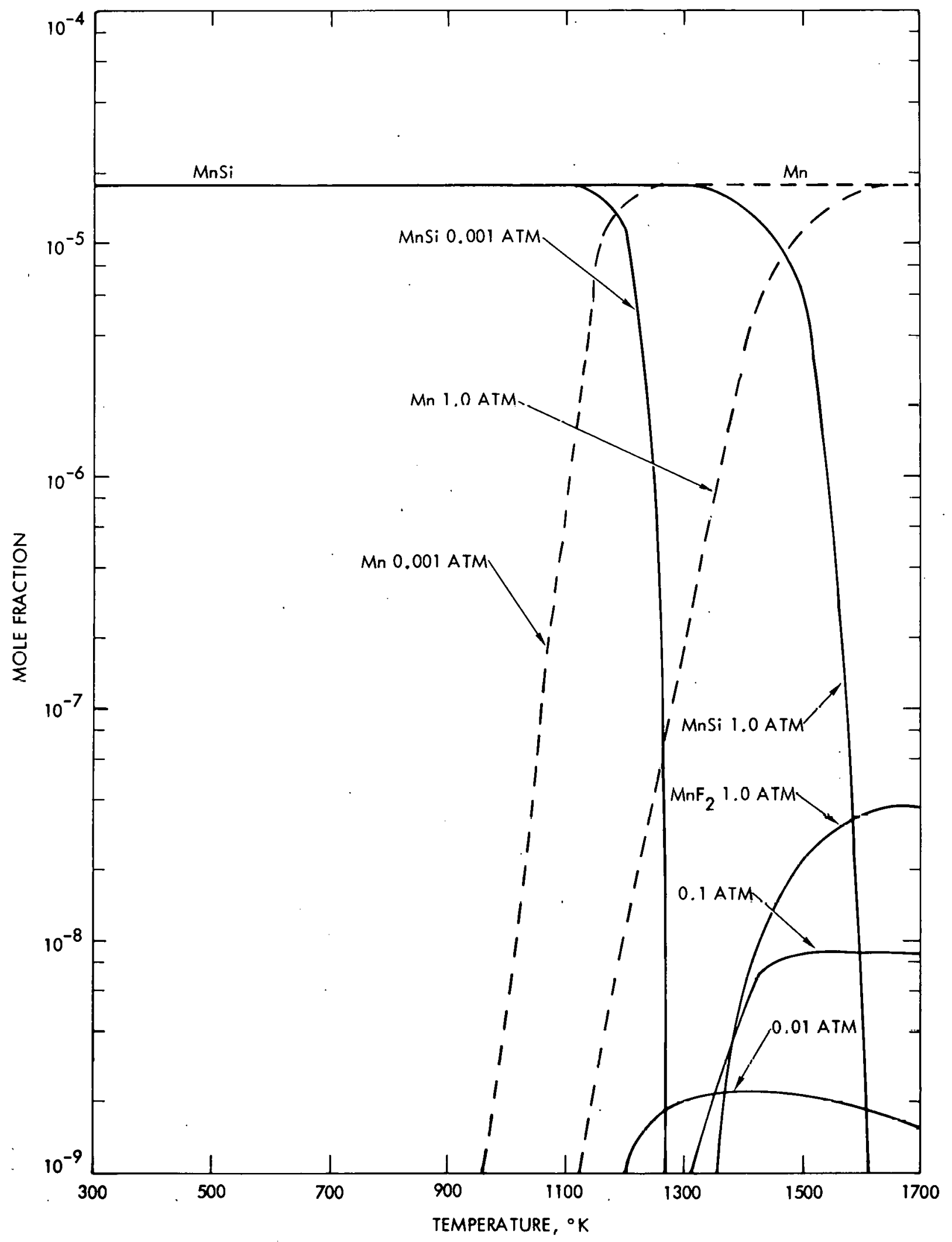

Figure 10. Computed Reaction Products from $70 \mathrm{ppm} \mathrm{Mn}$ in Si, Reacting with Equimolar $\mathrm{SiF}_{4}$ 


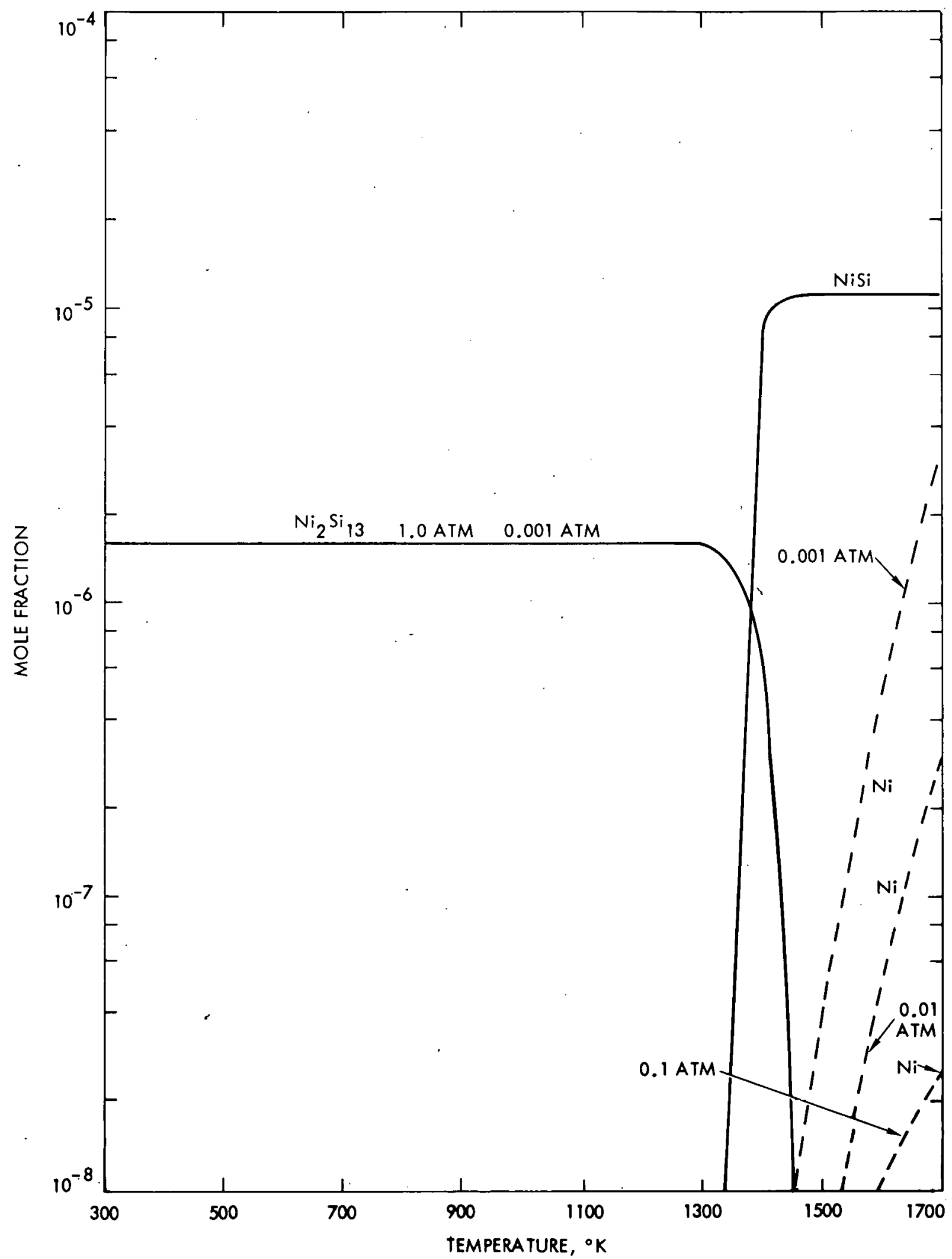

Figure 11. Computed Reaction Products from $47 \mathrm{ppm} \mathrm{Ni}$ in $\mathrm{Si}$, Reacting with Equimolar $\mathrm{SiF}_{4}$ 


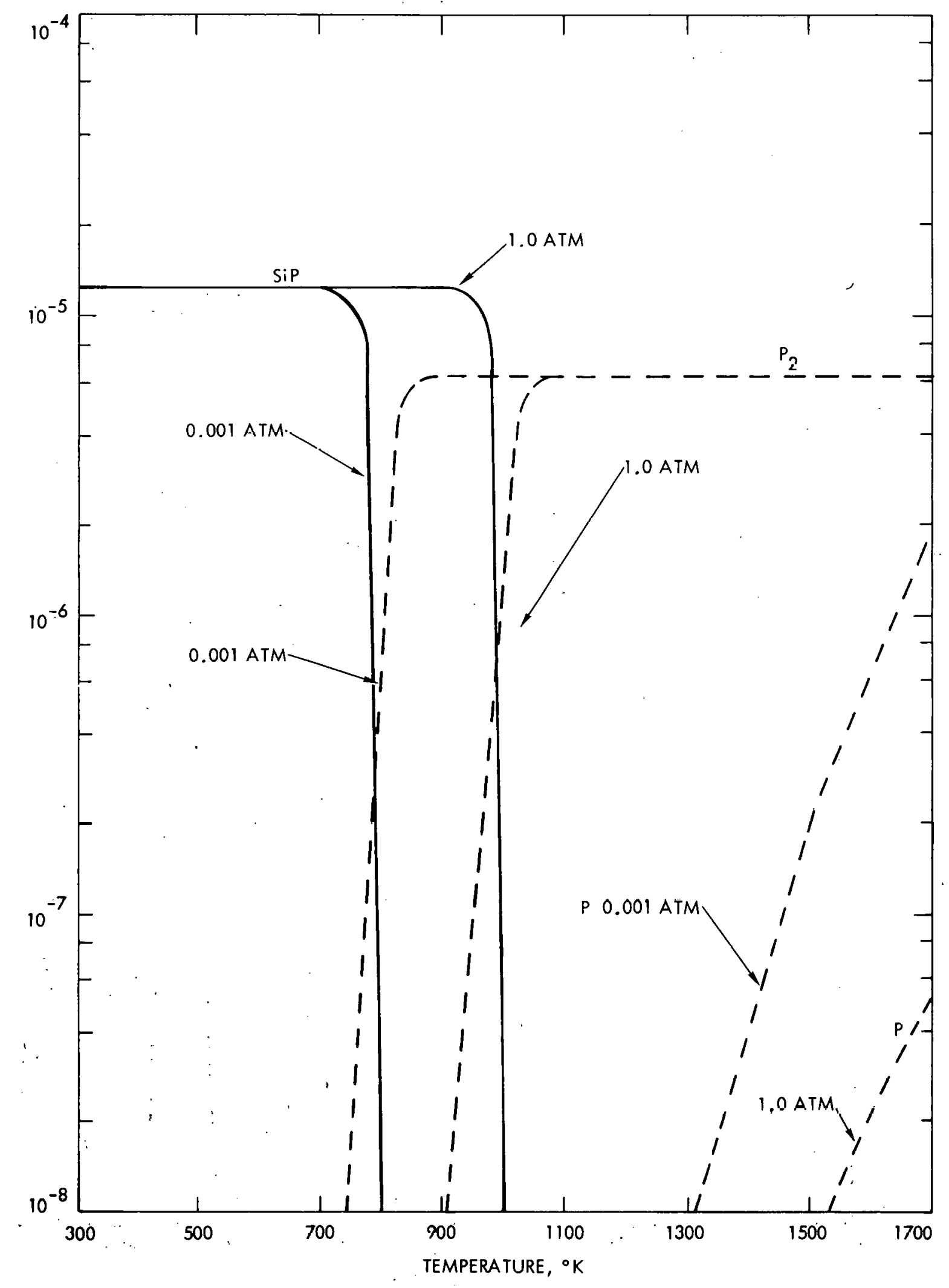

Figure 12. Computed Reaction Products from $28 \mathrm{ppm} P$ in Si, Reacting with Equimolar $\mathrm{SiF}_{4}$ 


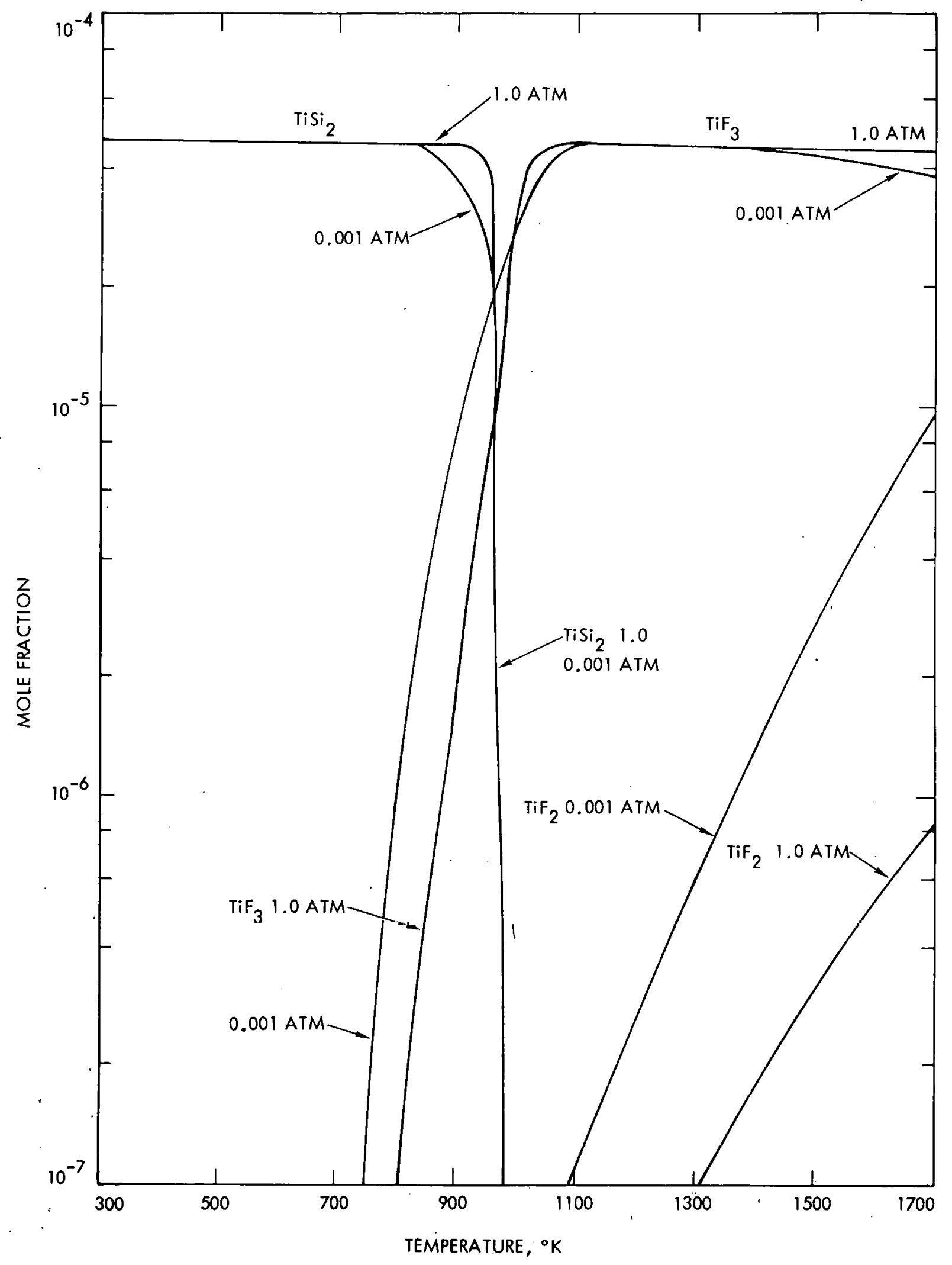

Figure 13. Computed Reaction Products from $163 \mathrm{ppm} \mathrm{Ti} \mathrm{in} \mathrm{Si,}$ Reacting with Equimolar $\mathrm{SiF}_{4}$ 


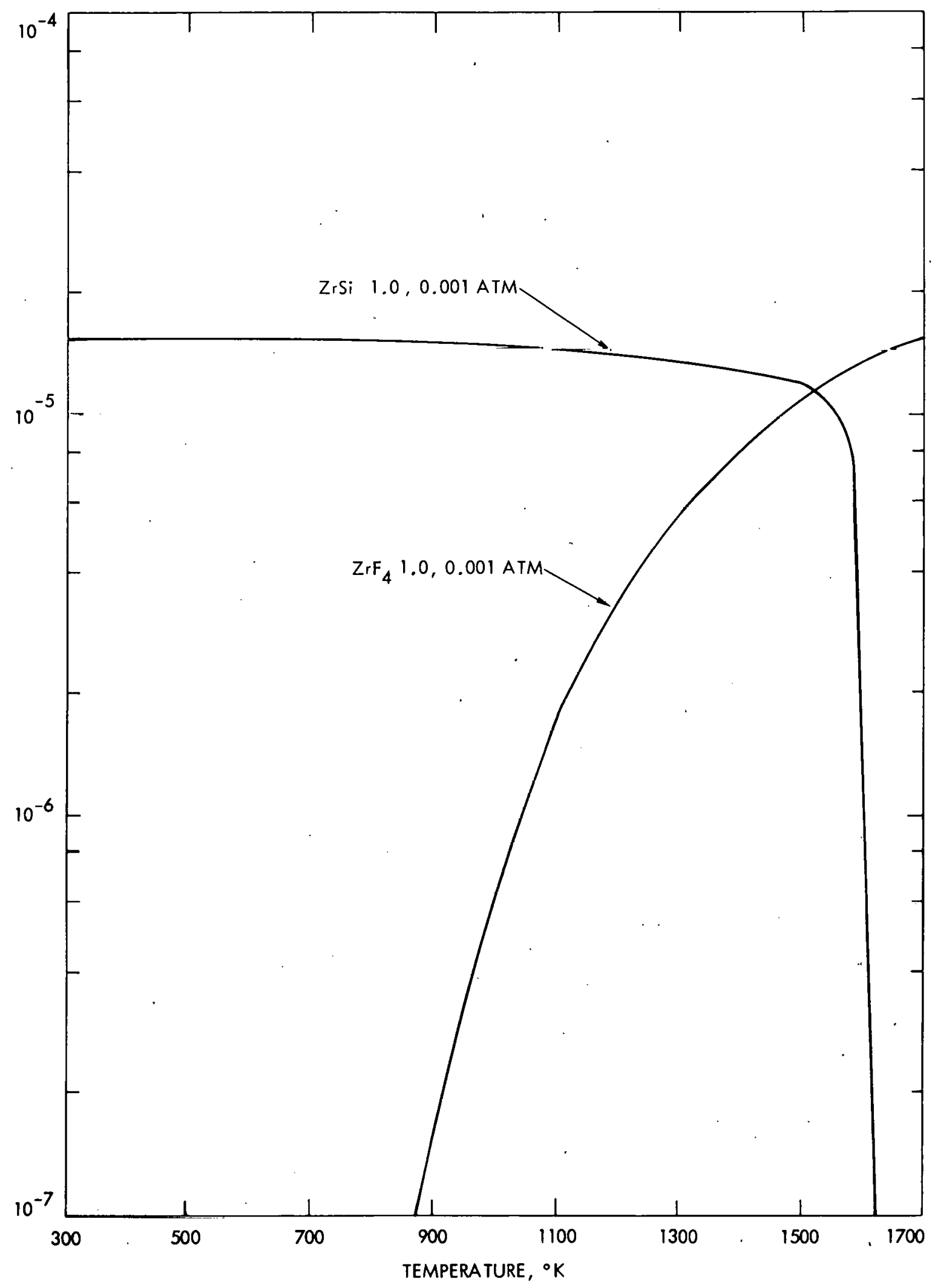

Figure 14. Computed Reaction Products from $100 \mathrm{ppm} \mathrm{Zr}$ in $\mathrm{Si}$, Reacting with Equimolar $\mathrm{SiF}_{4}$ 


\section{REFERENCES}

1. Ingle, W. M., Chaney, R., Thompson, S., Rosler, R., and Jackson, J., "Semiconductor Grade, Solar Silicon Purification Project," Motorola, Inc., Semiconductor Group, Phoenix, Arizona, ERDA/JPL 954442-77/3, Quarterly Progress Report No. 6, July 1977.

2. Pease, D. C., Difluorosylylene and Its Polymers, U. S. Patent No. 2,840,588, June 24, 1958 .

3. Timms, P. L., Kent, R. A., Ehlert, T. C., and Margrave, J. L., "Silicon-Fluorine Chemistry. I. Silicon Difluoride and the Perfluorosilanes," J. Am. Chem. Soc., Vol. 87, No. 13, pp. 2824-2828, 1965 .

4. Timms, P. L., et al, "Sume-Properties of Silicon Difluoride," Nature, Vol. 207, pp. 177-178, 1965.

5. Margrave, J. L., and Wilson, P. W., "Silicon Difluoride, a Carbene Analog. Its Reactions and Properties," Accounts Chem. Res., Vol. 4, pp. 145-151, 1971.

6. Adams, G. P., Sharp, K. G., Wilson, P. W., and Margrave, J. L., "Silicon-Fluorine Chemistry. XII. Enthalpy of Formation of Polydifluorosilylene and the Silicon-Silicon Bond Energy," J. Chem. Thermodynamics, Vol. 2, pp. 439-443, 1970.

7. Bassler, J. M., Timms, P. L., and Margrave, J. L., "Infrared Studies of $\mathrm{SiF}_{2}$ and Its Reactions in Low-Temperature Matrices," Inorg. Chem., Vol. 5, pp. 729-732, 1966.

8. Ingle, W. M., et al, "Semiconductor Grade, Solar Silicon Purification Project," Motorola, Inc., Semiconductor Group, Phoenix, Arizona, ERDA/JPL 954442-77/4, Quarterly Progress Report No. 7, Oct. 1977.

9. Gordon, S., and McBride, B., "Computer Program for Calculation of Complex Chemical Equilibrium Compositions, Rocket Performance, Incident and Reflected Shocks, and Chapman-Joughet Detonations," NASA SP-273, 1971 .

10. Hunt, L. P., "Low-Cost Processes for Integrated Solar Arrays," Final Progress Report, NSF/RANN No. GI-29729, ERDA No. EC $(11-1)-2721$, Dec. 1975 .

11. Barin, I., and Knacke, 0., Thermochemical Properties of Inorganic Substances, Springer-Verlag, New York, 1973.

12. Barin, I., Knacke, 0., and Kubaschewski, 0., Thermochemical Properties of Inorganic Substances -- Supplement, Springer-Ver lag, New York, 1977.

13. Brewer, L., et a1, "Thermodynamic Properties of Gaseous Metal Dihalides," Chem. Rev., Vol. 63, pp. 111-121, 1963. 
14. Hopkins, R. H., et al, "Effect of Impurities and Processing on Silicon Solar Cells," Westinghouse R\&D Center, Pittsburgh, Pennsylvania, DOE/JPL-954331-78/2, Quarterly Progress Report No. 10,1978 .

15. Hil1, D. E., et al, "The Effect of Secondary Impurities on Solar Cel1 Performance," pp. 112-119, 12th IEEE Photovoltaic Specialists Conference, Baton Rouge, Louisiana, Nov. 1976.

16. Ingle, W. M., et al, "Semiconductor Grade, Solar Silicon Purification Project," Motorola, Inc., Semiconductor Group, Phoenix, Arizona, ERDA/JPL-954442-76/2, Quarterly Progress Report No. 2, July 1976.

17. Kanaan, A. S., and Margrave, J. L., "Evidence for the Stability of Complex Silicon-Fluorine Species at High Temperatures," Inorg. Chem., Vol. 3, pp. 1037-1038, 1964.

18. Wolf, M., MacDiarmid, A. G., Noel, G. T., and Thallum, K., "Silicon Fluoride Transport: Summary of Current Results and Interim Assessment," pp. 137-145, 12th IEEE Photovoltaic Specialists Conference, Baton Rouge, Louisiana, Nov. 1976.

19. Corning Glass Works, Laboratory Products Catalog, Corning, New York, p. 11, 1971 .

20. Dushman, S., Scientific Foundations of Vacuum Techniques, Wiley, New York, 1966. 